\title{
Action Proof: Analyzing Elementary School Students Informal Proving Stages through Counter-examples
}

\section{Firana Amir 1, Mohammad Faizal Amir ${ }^{2 *}$}

\author{
1,2 Pendidikan Guru Sekolah Dasar, Universitas Muhammadiyah Sidoarjo, Sidoarjo, Indonesia
}

\section{ART ICLE INFO}

Article history:

Received June 05, 2021

Revised June 09, 2021

Accepted August 02, 2021

Available online August 25, 2021

Kata Kunci:

Bukti Tindaka, Counter-

Example,; Conjecture

Keywords:

Actionproof, Counter-Examples, Conjectures

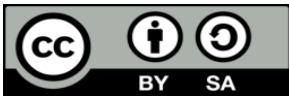

This is an open access article under the CC BY-SA license.

Copyright (C) 2021 by Author.

Published by Universitas Pendidikan Ganesha.

\begin{abstract}
A B S T R A K
Siswa perempuan dan laki-laki sekolah dasar masih mengalami kesulitan dalam melakukan action proof dengan menggunakan objek-objek manipulative untuk memberikan conjectures dan bukti kebenaran dari suatu pernyataan matematis. Sementara, counter-examples dapat membantu siswa sekolah dasar untuk membangun tahapan pembuktian informal dalam rangka mengajukan conjectures dan bukti kebenaran dari suatu pernyataan matematis secara lebih tepat. Tujuan penelitian ini adalah untuk menganalisis tahapan action proof melalui stimulisasi counter-examples pada siswa laki-laki dan perempuan sekolah dasar. Tahapan action proof dalam studi ini berfokus pada tiga tahapan, yaitu, proved their primitive conjecture, confronted counter-examples, and re-examining the conjecture and proof. Jenis penelitian yang digunakan adalah kualitatif dengan pendekatan studi kasus. Subjek penelitian adalah dua dari 40 siswa kelas $V$ yang dipilih secara purposive. Instrumen penelitian yang digunakan adalah tugas pembuktian dan pedoman wawancara. Teknik pengumpulan data terdiri atas penugasan, dokumentasi, dan wawancara. Teknik analisis data terdiri atas tiga tahapan yaitu reduksi data, penyajian data, dan penarikan simpulan. Hasil analisis menunjukkan bahwa pada tahap proved their primitive conjecture, conjectures yang dibuat oleh siswa perempuan dan laki-laki melalui bukti tindakan dengan menggunakan objek manipulative masih salah. Pada tahap confronted counterexamples, conjectures dan bukti-bukti yang dibuat oleh siswa perempuan dan laki-laki menunjukkan adanya perbaikan. Pada tahap re-examining the conjecture and proof, conjectures dan bukti-bukti oleh siswa perempuan dan laki-laki telah komprehensif. Disimpulkan bahwa tahapan-tahapan bukti tindakan siswa perempuan dan laki-laki menggunakan objek-objek manipulative melalui stimulisasi counter-examples menunjukkan adanya perbaikan conjectures dan bukti yang lebih komprehensif.
\end{abstract}

\section{A B S T R A C T}

Both female and male elementary school students have difficulty doing action proof by using manipulative objects to provide conjectures and proof of the truth of a mathematical statement. Counter-examples can help elementary school students build informal proof stages to propose conjectures and proof of the truth of a mathematical statement more precisely. This study analyzes the action proof stages through counter-examples stimulation for male and female students in elementary schools. The action proof stage in this study focuses on three stages: proved their primitive conjecture, confronted counter-examples, and re-examined the conjecture and proof. The type of research used is qualitative with a case study approach. The research subjects were two of the 40 fifth-grade students selected purposively. The research instrument used is the task of proof and interview guidelines. Data collection techniques consist of Tasks, documentation, and interviews. The data analysis technique consists of three stages: data reduction, data presentation, and concluding. The analysis results show that at the stage of proving their primitive conjecture, the conjectures made by female and male students through action proofs using manipulative objects are still wrong. At the stage of confronted counter-examples, conjectures and proof made by female and male students showed an improvement. At the stage of re-examining the conjecture and proof, the conjectures and proof by female and male students were comprehensive. It can be concluded that the stages of proof of the actions of female and male students using manipulative objects through stimulation counter-examples indicate an improvement in conjectures and more comprehensive proof.

\section{INTRODUCTION}

The proof is an important topic at the elementary school level. Unlike the junior or senior high school level, proof at the elementary school level focuses on the use of object manipulation (Liggett, 2017; Shinno \& Fujita, 2021). Object manipulation is included in informal proof, where elementary school students can use concrete media representing abstract mathematical objects to prove whether a mathematical statement is true or false (Buchbinder \& Zaslavsky, 2019; Lanitis, 2020). Elementary school students need the ability to prove informally before facing formal proof at the next level (Setiawan, 2020; 
Suandito, 2017). Besides, the informal proof is useful for students to experience rediscovering meaningful mathematical ideas (Suandito, 2017; Zazkis \& Villanueva, 2016).

One type of informal proof at the elementary school level is action proof. Action proof at the elementary school level is an instructional method that enables students to develop their basic mathematical skills (Wittmann, 2021). Action proof is important given to elementary school students to achieve formal proof (Miyazaki et al., 2019; Shinno \& Fujita, 2021). The role of action proof is to verify the truth of a mathematical statement with the help of manipulative objects in the form of physical objects (Fadiana et al., 2021; Shinno \& Fujita, 2021). Action proof through object manipulation helps introduce proof problems in the early stages of learning mathematics for elementary students (Liggett, 2017). Elementary school students who are in the age group 7-12 years and the concrete operational stage (Byrnes, 2016; Halford, 2017). This will have implications for good mathematics habituation and experience for students from elementary to intermediate levels (Regier \& Savic, 2020; Setiawan, 2020).

Although action proof through the use of manipulative objects has positive implications for the construction of informal proofs for elementary school students, they fail to perform action proofs through the use of logical manipulative objects (Liggett, 2017). The facts of previous research also show the difficulties of elementary school students in manipulating objects in action proof. The previous research found that students had difficulty making comprehensive conjectures while manipulating physical objects in action proof (Brunner \& Reusser, 2019). In another research, it was found that the ease of using manipulative objects only lies in the initial step of the proof, but students have difficulty in making abstract conjectures in the next step (Liggett, 2017). Meanwhile, using other terms from action proof (operative proof), found that students had difficulty manipulating objects when sorting physical objects with numbers according to the command questions (Shinno \& Fujita, 2021). As a result, elementary school students will find it difficult to complete proof both informally and formally at the next level of education. Therefore, giving action proof using manipulative objects important for elementary school students to develop logical thinking skills and succeed in formal proof (Setiawan, 2020; Suandito, 2017).

Counter-examples are mathematical proof methods to show that a conjecture is true or false (Yopp, 2020). Counter-examples of mathematical conjectures made by students can help them evaluate the truth and refine them (Barahmand, 2019; Zeybek, 2017). In addition, counter-examples help students better understand a mathematical concept being studied (Barahmand, 2019). Counter-examples are important components in teaching and learning mathematics that verify statements that can change thoughts or work to get better solutions (Buchbinder \& Zaslavsky, 2019; Regier \& Savic, 2020). Thus, the difficulty of elementary school students in doing action proof lies in the failure of students to make logicalmathematical conjectures when manipulating objects. In this study, counter-examples are useful for stimulating students' mathematical conjectures when manipulating physical objects in action proofs. The purpose of this counter-examples stimulation is for students to be aware of the mathematical conjecture errors made and justify them into more comprehensive mathematical conjectures to prove the truth of a mathematical statement.

Based on the study of the literature and previous studies above, the stages of action proof in using manipulative objects through stimulation of counter-examples to improve the mathematical conjectures of elementary school students are important for further analysis. The difficulties and failures of elementary school students in making mathematical conjectures require further study. These mathematical conjectures also need to be corrected through counter-examples stimulation while manipulating objects in action proofs so that students' proof skills can lead to formal proofs. In addition, research has not been found on the analysis of the stages of action proof through counter-examples stimulation by taking into account the gender differences of elementary school students is also a necessity. In fact, analyzing the stages of cognitive development of elementary school students through a review of gender differences is important to determine student success factors (Bujuri, 2018; Juwantara, 2019; Susilowati, 2016). Biological differences in the brains of boys and girls also affect their mental activity (Astawa, 2020; Sokolowski et al., 2019). Thus, the purpose of this study was to analyze the stages of action proof in using manipulative objects through stimulation of counter-examples on female and male elementary school students.

\section{METHOD}

This research is qualitative research with a qualitative descriptive approach using the type of case study research. A case study is a series of scientific activities carried out intensively, in detail, and deeply about an event or activity on an object to obtain in-depth results about the event (Cresswell, 2012). The case study in this study was conducted by analyzing selected male and female students about the stages of action proof in using manipulative objects through counter-examples stimulation. 
Two of the 40 fifth-grade students SDN Karangpuri in odd semester academic year 2020-2021 were determined using the purposive sampling technique. The criteria for the subject in this research were sex categories (female and male students), ability to communicate ideas in providing action proof the statements, and correct mathematical conjectures when stimulated using counter-examples. Subjects were selected in several stages through Zoom Meeting, work closely with the classroom teacher to get a purposively representative subject. In the first stage, the researcher observed the students' ability to prove through the question, "is it true that the result of multiplying an odd number by an even number is always an even number." The result of this stage was that 25 out of 40 students succeeded in proving the statement logically. The second stage provided teaching proof through action proof. In the third stage, students were instructed to look for counter-examples through action proof from mathematical statements on whole number material, namely "any addition between an odd number and an even number is a prime number." In this case, only two students can prove that the statement is false through action proof by providing one counter-examples, which is $3+6=9$ that 9 is not a prime number. The two students are Subject 1 (S1), a female student, and Subject 2 (S2), a male student.

The research instrument consisted of a proof task and an interview guide. The task of proof was adapted from Komatsu, which was about mathematical statements on the addition of whole numbers that must be checked for truth values using manipulative objects (Komatsu, 2010). The statement was "if the result of the addition of a two-digit whole number with an integer whose digits are opposite, then the result is a two-digit whole number with the same tens and units digits, with different numerical conjectures, namely; $42+24=66$. Check the truth value using the available concrete objects". The concrete objects are manipulative in the form of red coins representing the unit value, green coins representing the tens value, and yellow coins representing the value of the hundreds. The interview guide is a series of questions prepared based on the indicators of the action proof stage through stimulation counter-examples (Komatsu, 2010), namely proved their primitive conjecture, confronted counterexamples, and re-examining the conjecture and proof (see Table 1).

Table 1. action proof indicator through counter-examples stimulation

\begin{tabular}{ll}
\hline \multicolumn{1}{c}{ Stages } & \multicolumn{1}{c}{ Indicators } \\
\hline Proved Their & Using object manipulatives to create primitive conjectures \\
Primitive & $\begin{array}{l}\text { Proving the truth of the given mathematical statement } \\
\text { Create and prove their primitive conjecture }\end{array}$ \\
$\begin{array}{l}\text { Conjecture } \\
\text { Confronted }\end{array}$ & $\begin{array}{l}\text { Using manipulative objects to respond counter-example } \\
\text { Proving the given counter-examples } \\
\text { Creating a new conjecture from the given counter-examples }\end{array}$ \\
$\begin{array}{l}\text { Re-Examining The } \\
\text { Conjecture And } \\
\text { Proof }\end{array}$ & $\begin{array}{l}\text { Using object manipulatives to find more comprehensive conjectures } \\
\text { Discover new, more comprehensive conjectures from proven counter-examples }\end{array}$ \\
\hline
\end{tabular}

Before being used, the task of proof and interview guidelines were checked for instrument validity through expert judgment. Expert judgment on the two instruments was carried out by two mathematics education experts and one elementary school education expert through content analysis on material, construction, and language aspects (Lestari \& Siregar, 2019). The validation results show that the verification task and interview guide are valid (appropriate to use) with revisions with a minimum value of $88 \%$ and $90 \%$, respectively. The revisions made were on the use of language to be more adapted to the cognitive level of elementary school students. Data collection techniques consisted of Tasks, interviews, and documentation which were conducted through Zoom Meetings. Tasks were carried out by providing proof task instruments to students who were selected as subjects. At the next meeting, subjects underwent interviews regarding the results of student proof work. Meanwhile, documentation is done by collecting all the subject results, recording the subject while working on the proof task, and recording interviews. The results of this documentation are the results of the subject's work, recordings of the subject during the proof task, and interview transcripts. The data analysis technique consists of three stages: data reduction, data presentation, and conclusion drawing (Miles et al., 2014). Data on student work and interview transcripts were reduced by separating data unrelated to action proof indicators through counter-examples stimulation, as presented in Table 1. Data presentation was done by representing the results of the subject's action proof in pictures. Then analyze and organize the data based on the stages of action proof descriptively. Meanwhile, conclusions are drawn by comparing the suitability of the data by triangulation and analysis of relevant theories. Triangulation conclusions are given when 
there are similarities between the student action proof images and the interview transcript analysis according to the students' action proof stages.

\section{RESULT AND DISCUSSION}

\section{Result}

Using object manipulatives in stimulation counter-examples of two subjects (S1 and S2) grade 5 elementary school were analyzed through three stages: proved their primitive conjecture, confronted counter-examples, and re-examined conjecture and proof. In the proved their primitive conjecture stage, S1 and S2 added $42+24$ and showed the result 66 . To prove the conjecture, S1 created a new primitive conjecture $31+13=44$, as shown in Figure 1 . S1 made a representation with a manipulative object with three green coins, which shows the thirties (30) and one red coin showing one unit (1), added up by one green coin showing one ten (10) and three red coins showing three units (3). At this addition stage, S1 has not represented the place value of a number correctly. As shown in Figure 1, S1 placed the coins according to the color and arranged them in such a way, not by placing them according to their place values. However, in the summation, S1 grouped her coins according to the color equation. S1 earned four green coins for the forties (40) and four red coins for four ones (4) (Figure 1). The primitive conjecture made by S1 was incorrect. S1 confirmed the statement given in the Task sheet that the result of adding a two-digit whole number with an integer whose digits were opposite. The result is a two-digit whole number with the same tens and units digits. In addition, S1 has not been able to place manipulative objects according to the place value of a number. However, she had already provided a color representation according to the value of a number.Meanwhile, S2 gave the primitive conjecture $32+23=55$, as shown in Figure 2 . S2 made a representation with a manipulative object in the form of three green coins, showing thirties (30) and two red coins showing two units (2) added up by two green coins, twenties (20), and three red coins show three ones (3). At this addition stage, S2 has correctly represented the place value of a number (See Figure 2). S2 had placed the color of the coin according to its place value. The sum result in Figure 2 also corresponds to the color equation and the place value of a number. S2 earned five green coins for the fifties (50) and five red coins for the fives (5). The primitive conjecture made by S2 was incorrect. S2 confirmed the statement given in the Task sheet that the result of the addition of a two-digit whole number with a whole number with the opposite digits is a two-digit whole number with the same tens and units digits. However, S2 has been able to place manipulative objects according to the place value of a number and represent colors according to the number value.

\section{Confronted Counter-examples}

The primitive conjectures given by S1 and S2 were still incorrect, so a counter-example needs to be applied to get a more in-depth analysis result. The researcher gave counter-example stimulation in the form of adding the number "85 + 58". S1 and S2 were asked to create conjectures using manipulative objects. At this stage, $\mathrm{S} 1$ had not placed the value of a number correctly, but the color representation of the manipulative object made was appropriate (See Figure 3 Part 1). She also could not use manipulative objects by placing the place values of numbers correctly. In Figure 3 Part 2, S1 faced 13 green coins representing tens and 13 red coins representing units, which means that the sum no longer produces two numbers indicating tens and ones. This made S1 faced difficulties and reread the statements in the Task Sheet. Because of the problem, S1 tried to solve the stacking calculations she usually used in class. The stacking results can change the coins, as shown in Figure 3 Part 3. S1 revealed that the results do not match the statements in the Task Sheet, so the counter-example makes it difficult. When the researcher asked, "were their conjectures wrong?" S1 replied that his calculation was correct, but the result was not the same as the primitive conjecture.

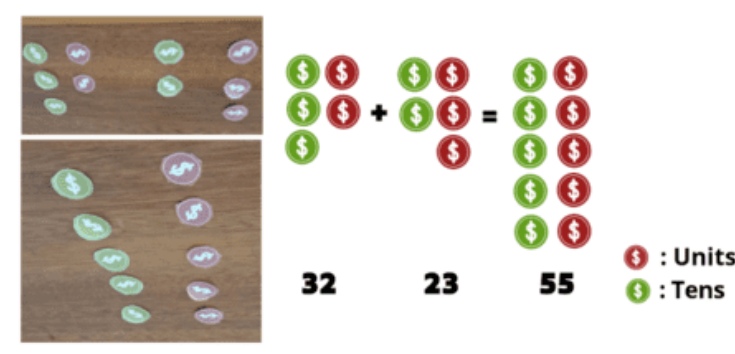

Figure 2. S2's action proof primitive conjecture

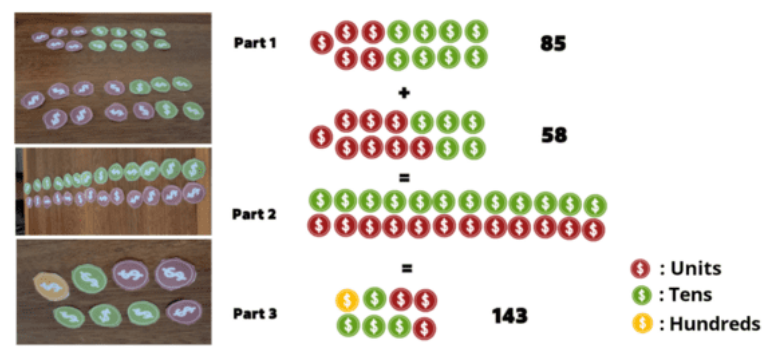

Figure 3. The process of calculating S1 counterexamples 
On the other hand, S2 completed counter-examples by using the manipulative object representation of eight green coins for the eighties (80) and five red coins for five ones (5), added up by five green coins for fifties (50) and eight red coins for eight units (8) (Figure 4 Part 1). At this stage, S2 was better at placing the value of a number. S2 had difficulty faced with Figure 4 Part 2 . He got 13 green and 13 red coins, neither of which represented the two-digit tens and one's digits. S2 remembers that he has a yellow coin that had not been used to represent the value of hundreds, so he immediately converted it into hundreds (Figure 4 Part 3). Knowing the results were not the same as the statement in the Task sheet, S2 had a hard time. When the researcher gives the statement "do you need help?" S2 said that he wants to solve it himself first. After a while, S2 revealed the new conjecture he had made. S2 revealed that "the result of the addition of a two-digit whole number with a whole number whose digits are opposite the result is a two-digit whole number with the same tens and units digits. However, when the number becomes three digits or more digits, the result will be different." The counter-examples in the action proof stage provided by S1 and S2 were still imperfect. However, S2 has shown that the counter-example was useful for repairing and modifying the primitive conjectures. The next step was needed to get to a comprehensive conjecture.

\section{Re-examined the Conjecture and Proof}

At this stage, students were asked to re-examine the conjectures they made so that the subject realized that the counter-examples they proved were not comprehensive. The researcher asked S1 and S2 to check the calculation of "85+58" from the action proof they made at the stage of making a counterexample (See Figure 3 or 4 part 2). The researcher asked the students to see from the descending order, look from the other side (horizontal arrangement), and see what happened? Are the coins the same amount? Students give answers if the horizontal arrangement is equal and in pairs. The result of the sum of the pairs is one green (10) and one red (1) is eleven. Next, the researchers led them to count the number of pairs in the calculation. Students answer 13 pairs, which are obtained from the addition of " $8+5$ or 5+8". Through this stimulation, students made new conjectures to achieve a more comprehensive conjecture in the form of the statement "the sum of a two-digit whole number with an inverse two-digit whole number will produce eleven times the sum of the two whole numbers, which means that the result of the addition is a multiple of 11". S2's new conjecture is true, "if the sum of an integer is two digits with an integer whose digits are reversed, the result is a multiple of 11" (Figure 5). Counter-examples are examples that satisfy the presumption but violate the conclusion (Buchbinder \& Zaslavsky, 2019; Yopp, 2020). In this case, the conjecture meets the conditions, but the conclusion is different.

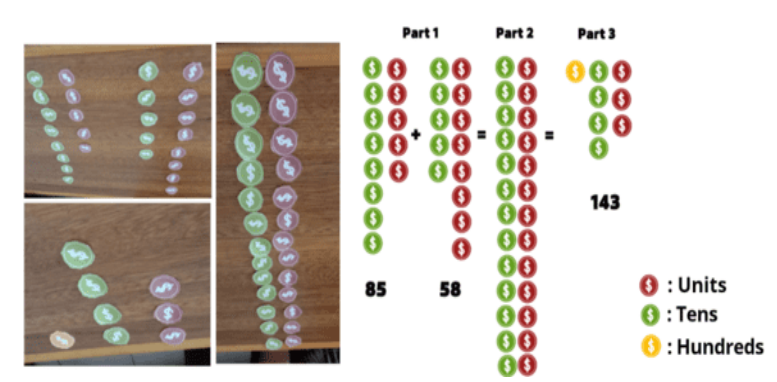

Figure 4. S2's counter-examples calculation process

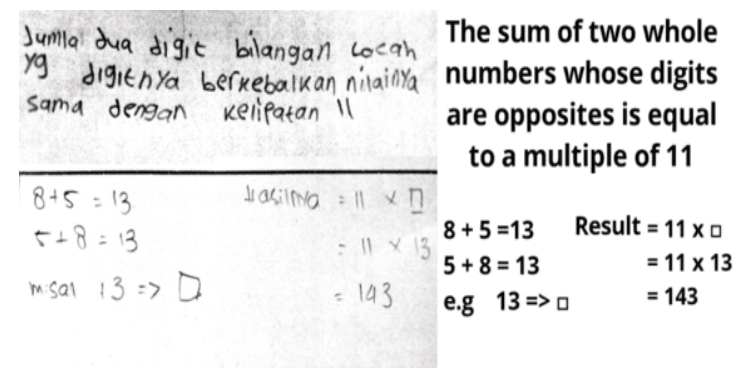

Figure 5. S2's New Conjecture and Proof

\section{Discussion}

From the results described above, when students prove their primitive conjecture, they make primitive conjectures that are still wrong. Therefore, a confronted counter-examples stage is required. Researchers provide counter-example stimulation that is useful for finding new conjectures and changing their primitive conjectures. At this stage, students have difficulty and confusion in completing the action proof when faced with a counter-example. However, they are trying to improve the primitive conjecture into a new conjecture which is not comprehensive yet. This interprets that students still have difficulty completing action proofs at certain stages (Komatsu, 2010; Shinno \& Fujita, 2021). The difficulty in completing this action proof occurs because students find that their conjectures are not the same as the existing statement because they are faced with counter-examples. This is in accordance with the function of counter-examples, namely evaluating the truth and perfecting the conjecture (Barahmand, 2019; Yopp, 2020). In the proved their primitive conjecture stage, the action proof performed by students is reflected when they carry out the proof process using manipulative objects. The manipulative objects used in this study are coins of different colors to represent the place value of a number. Manipulative objects given by 
female students are not appropriate in representing the place value of a number. In addition, students confirmed the statement that "the result of the addition of a two-digit whole number with a whole number whose digits are opposites is a two-digit whole number with the same tens and units digits." That is, the primitive conjecture they provide is incorrect. Students still experience failure in the use of logical manipulative objects (Komatsu, 2010; Liggett, 2017). This occurs because the primitive conjecture has generated the same conjecture as the statement. So the statement they give will also be the same as the statement. Because the assumptions they gave were still wrong at this stage, the next stage of action proof was needed.

In this confronted counter-examples stage, students are faced with counter-examples. Through this stimulation, they realized that the primitive conjecture they had proven earlier was still not true. The provision of counter-examples in this action proof is made to provide stimulation so that students are aware of the errors in the initial conjectures made and justify them into more comprehensive mathematical conjectures (Barahmand, 2019; Zazkis \& Villanueva, 2016). So, he tried to make a new conjecture that "the result is a two-digit whole number with the tens and ones being the same when the sum becomes three digits or the digits are more then the numbers are different". Students show the effect of counter-examples stimulation; although they have corrected the new conjecture, it is still not perfect. The counter-examples stimulation provided did not make them just give up. These stages show counterexample plays a good role in verifying a statement that can change thoughts or ways of working to help readjust the perception or primitive conjecture they make (Yopp, 2020; Zazkis \& Villanueva, 2016). The new conjecture's imperfection occurred because students still did not properly represent the manipulative object. Therefore, the third stage is needed to get to more comprehensive conjectures.

At the stage of re-examining the conjecture and proof, students complete a new, more comprehensive conjecture. Using the results of the action proof they made at the stage of completing counter-examples, the researchers provided verbal stimulation to lead to the correct answer. Students are actively refining conjectures so that new, more comprehensive conjectures are obtained. Although manipulative objects are not effective in their application, with the help of these manipulative objects, the conjectures they provide can be represented in real terms so that the understanding of primitive conjectures and the new conjectures they provide can be proven. The use of manipulative objects has not yet had a good impact. Still, these manipulative objects provide authentic or tangible proof that elementary school students easily accept (Liggett, 2017; Miyazaki et al., 2019). There is a difference between the completion of mathematical proofs by female students and male students. Male students understand the concept and use of manipulative objects to represent each stage in the action proof. Meanwhile, female students still have confusion in applying manipulative objects and understand better if the usual abstract method is used in classroom learning. Thus, male students provide action proof with manipulative objects better than female students. This conforms with the result of Guez et al. (2020); Oppermann et al. (2021) that the numeracy ability of male students is better than female students, but it is in contrast with Nugraha \& Pujiastuti (2019), who revealed that in terms of cognitive female students and male students have a low percentage of differences.

Action proof is one way to develop the basic skills needed in mathematics in the last 20 years (Wittmann, 2021). Besides, it takes time to understand and broad skills and knowledge to prove a fact (Siswono et al., 2020). This happens in every step process carried out by students to arrive at the correct statements and conjectures. They do not immediately get the facts quickly but must go through every stage to arrive at the new conjecture. Thus, the role of the teacher in teaching proof intuitively in elementary school mathematics learning in the classroom is needed so that at the next level of education, students have the experience that can be used to complete proof formally. Thus, providing proof experience to elementary school students through the action proof stage with counter-examples stimulation is highly recommended to improve students' conjectures. In addition, elementary school students have the logical proof experience to form formal proof skills at the next level. This study only uses a few subjects with certain criteria. So that, the results of the research given cannot be said to be general for all elementary school students. For the study results to be more general, further research is recommended to involve a larger number of participants while applying counter-examples stimulation to improve students' mathematical assumptions in action proof.

\section{CONCLUSION}

The stages of action proof through stimulation of counter-examples for male and female elementary school students have improved towards comprehensive conjectures and proof of truth. In the proved their primitive stage, male and female students make primitive conjectures using manipulative objects. However, the primitive conjectures they gave were still incorrect. In the confronted counter- 
examples stage, female and male students gave new conjectures with manipulative objects, which showed improvement but were not comprehensive. At the re-examining of the conjecture and proof stage, students are stimulated to refine manipulative things into comprehensive conjectures.

\section{REFERENCES}

Astawa, I. W. P. (2020). The Differences in Students ' Cognitive Processes in Constructing Mathematical Conjecture. Jurnal Pendidikan Indonesia, 9(1), 49-60. https://doi.org/10.23887/jpiundiksha.v9i1.20846.

Barahmand, A. (2019). On Mathematical Conjectures and Counterexamples. 9(1). https://doi.org/10.5642/jhummath.201901.17.

Brunner, E., \& Reusser, K. (2019). Type of Mathematical Proof : Personal Preference or Adaptive Teaching Behavior ? ZDM, 51(5), 747-758. https://doi.org/10.1007/s11858-019-01026-y.

Buchbinder, O., \& Zaslavsky, 0. (2019). Strengths and Inconsistencies in Students' Understanding of the Roles of Examples in Proving. Journal of Mathematical Behavior, 53, 129-147. https://doi.org/10.1016/j.jmathb.2018.06.010.

Bujuri, D. A. (2018). Analisis Perkembangan Kognitif Anak Usia Dasar dan Implikasinya dalam Kegiatan Belajar Mengajar. LITERASI (Jurnal Ilmu Pendidikan), 9(1), 37-50. https://doi.org/10.21927/literasi.2018.9(1).37-50.

Byrnes, J. P. (2016). Piaget's Cognitive-Developmental Theory. The Curated Reference Collection in Neuroscience and Biobehavioral Psychology, April, 543-552. https://doi.org/10.1016/B978-0-12809324-5.23519-0.

Cresswell, J. W. (2012). Planning, Conducting, and Evaluating Quantitative and Qualitative Research. Educational Research, 10,1-12. https://doi.org/10.4135/9781483349435.

Fadiana, M., Yulaikah, \& Lajianto. (2021). Tipe Pembuktian Mahasiswa Calon Guru Matematika. AKSIOMA: Jurnal Program Studi Pendidikan Matematika, 10(1), 351-358. https://doi.org/10.24127/ajpm.v10i1.3443.

Guez, A., Peyre, H., \& Ramus, F. (2020). Sex Differences in Academic Achievement are Modulated by Evaluation Type. Learning and Individual Differences, 83-84(January), 101935. https://doi.org/10.1016/j.lindif.2020.101935.

Halford, G. S. (2017). Cognitive Developmental Theories. Reference Module in Neuroscience and Biobehavioral Psychology, 1-11. https://doi.org/10.1016/B978-0-12-809324-5.05787-4.

Juwantara, R. A. (2019). Analisis Teori Perkembangan Kognitif Piaget pada Tahap Anak Usia Operasional Konkret 7-12 Tahun dalam Pembelajaran Matematika. Al-Adzka: Jurnal Ilmiah Pendidikan Guru Madrasah Ibtidaiyah, 9(1), 27. https://doi.org/10.18592/aladzkapgmi.v9i1.3011.

Komatsu, K. (2010). Counter-examples for Refinement of Conjectures and Proofs in Primary School Mathematics. Journal of Mathematical Behavior, 29(1), 1-10. https://doi.org/10.1016/j.jmathb.2010.01.003.

Lanitis, A. (2020). Comparative Evaluation of Virtual and Augmented Reality for Teaching Mathematics in Primary Education. Education and Information Technologies, 25, 381-401. https: //doi.org/10.1007/s10639-019-09973-5.

Lestari, A. D., \& Siregar, H. P. (2019). Analisis Butir Soal Matematika Buatan Guru SMP Negeri 1 Mempura. Pi: Mathematics Education Journal, 2(1), 26-33. https://doi.org/10.21067/pmej.v2i1.2837.

Liggett, R. S. (2017). The Impact of Use of Manipulatives on the Math Scores of Grade 2 Students. Brock Education Journal, 26(2), 87-101. https://doi.org/10.26522/brocked.v26i2.607.

Miles, M. B., Huberman, A. M., \& Saldana, J. (2014). Qualitative Data Analysis: A Methods Sourcebook (Third Edit). SAGE Publications, Inc.

Miyazaki, M., Nagata, J., Chino, K., Sasa, H., Komatsu, K., Fujita, T., \& Shimizu, S. (2019). Curriculum Development for Explorative Proving in Lower Secondary School Geometry: Focusing on the Levels of Planning and Constructing a Proof. Frontiers in Education, 4(April), 1-9. https://doi.org/10.3389/feduc.2019.00031.

Nugraha, T. H., \& Pujiastuti, H. (2019). Analisis Kemampuan Komunikasi Matematis Siswa Berdasarkan Perbedaan Gender. Edumatica: Jurnal Pendidikan Matematika, 09(1), 1-7. https: //doi.org/10.22437/edumatica.v9i1.5880.

Oppermann, E., Vinni-Laakso, J., Juuti, K., Loukomies, A., \& Salmela-Aro, K. (2021). Elementary School Students' Motivational Profiles Across Finnish Language, Mathematics and Science: Longitudinal Trajectories, Gender Differences and STEM Aspirations. Contemporary Educational Psychology, 64(November 2020), 101927. https://doi.org/10.1016/j.cedpsych.2020.101927.

Regier, P., \& Savic, M. (2020). How Teaching to Foster Mathematical Creativity May Impact Student Self- 
efficacy for Proving. Journal of Mathematical Behavior, 57(June), 100720. https://doi.org/10.1016/j.jmathb.2019.100720.

Setiawan, Y. E. (2020). Analisis Kemampuan Siswa dalam Pembuktian Kesebangunan Dua Segitiga. AlKhwarizmi: Jurnal Pendidikan Matematika dan Ilmu Pengetahuan Alam, 8(1), 23-38. https://doi.org/10.24256/jpmipa.v8i1.800.

Shinno, Y., \& Fujita, T. (2021). Characterizing How and When a Way of Proving Develops in a Primary Mathematics Classroom: a Commognitive Approach. International Journal of Mathematical Education in Science and Technology. https://doi.org/10.1080/0020739X.2021.1941365.

Siswono, T. Y. E., Hartono, S., \& Kohar, A. W. (2020). Deductive or Inductive? Prospective Teachers' Preference of Proof Method on an Intermediate Proof Task. Journal on Mathematics Education, 11(3), 417-438. https://doi.org/10.22342/jme.11.3.11846.417-438.

Sokolowski, H. M., Hawes, Z., \& Lyons, I. M. (2019). What Explains Sex Differences in Math Anxiety? A Closer Look at the Role of Spatial Processing. Cognition, 182(October 2018), 193-212. https://doi.org/10.1016/j.cognition.2018.10.005.

Suandito, B. (2017). Bukti Informal dalam Pembelajaran Matematika. Al-Jabar: Jurnal Pendidikan Matematika, 8(1), 13-24. https://doi.org/10.24042/ajpm.v8i1.1160.

Susilowati, J. P. A. (2016). Profil Penalaran Siswa SMP dalam Pemecahan Masalah Matematika Ditinjau dari Perbedaan Gender. Jurnal Review Pembelajaran Matematika, 1(2), 132-148. https: //doi.org/10.15642/jrpm.2016.1.2.132-148.

Wittmann, E. C. (2021). Connecting Mathematics and Mathematics Education. Connecting Mathematics and Mathematics Education, 223-238. https: //doi.org/10.1007/978-3-030-61570-3.

Yopp, D. A. (2020). Eliminating Counterexamples: An Intervention for Improving Adolescents' Contrapositive Reasoning. Journal of Mathematical Behavior, 59, 100794. https: //doi.org/10.1016/j.jmathb.2020.100794.

Zazkis, D., \& Villanueva, M. (2016). Student Conceptions of What it Means to Base a Proof on an Informal Argument. International Journal of Research in Undergraduate Mathematics Education, 2(3), 318337. https://doi.org/10.1007/s40753-016-0032-3.

Zeybek, Z. (2017). Pre- service Elementary Teachers ' Conceptions of Counterexamples. International Journal of Education in Mathematics, Science and Technology, 5(4). https://doi.org/10.18404/ijemst.70986. 